\title{
CEACAM6 wt Allele
}

National Cancer Institute

\section{Source}

National Cancer Institute. CEACAM6 wt Allele. NCI Thesaurus. Code C107470.

Human CEACAM6 wild-type allele is located in the vicinity of $19 q 13.2$ and is approximately $17 \mathrm{~kb}$ in length. This allele, which encodes carcinoembryonic antigen-related cell adhesion molecule 6 protein, plays a probable role in both cell adhesion and cell-cell signaling. 